\title{
Cultured Technology: \\ Internet and Religious Fundamentalism
}

\author{
Karine Barzilai-Nahon*, Gad Barzilai**
}

\begin{abstract}
:
This paper presents a theoretical framework to understand the relationship between religious fundamentalist communities and the Internet, through addressing four dimensions of tensions and challenges: hierarchy, patriarchy, discipline, and seclusion. We develop the concept of cultured technology, and analyze the ways communities reshape technology and make it as part of the ir culture, while on the other hand allowing this technology to make certain changes in their customary way of life and in their unwritten laws. Later, we exemplify our theoretical framework through an empirical examination of ultra-Orthodox Jewish communities in Israel. Our empirical study is based on original dataset of 686,192 users and 60,346 virtual communities, while also relying on extensive literature review and secondary data. The results show the complexity of interactions between religious fundamentalism and Internet, and invite further discussions of cultured technology as a means to adapt Internet and to be adapted into it in various communities that incline to challenge technological innovations.
\end{abstract}

Keywords: cultured technology, localization, virtual communities, religious fundamentalism, online interactions, control and censorship, hierarchy, patriarchy, discipline, social capital, digital divide, cyberspace. 


\section{Introduction:}

The interaction between innovative information technology (thereafter: IT) and religion is often perceived as contradictory, especially when it is religion at its most conservative practice. The most prominently perceived conflict is between religious fundamentalism and telecommunications, since cyberspace, through the development of both local and global networks and software, has expanded immensely. Yet religions remain as meaningful ways of life around the globe and are not excluded from the Internet (Hojsgaard and Warburg, 2004 forthcoming, , Hadden and Cowan, 2000, , Dawson and Cowan, 2004 forthcoming). While international and national IT policies promote the globalization and localization of Internet standards and applications, local religious communities, especially fundamentalists, vigorously resist such policies if and when they perceived them as a threat to their local cultures and practices (Lawrence, 2000).

We look at the Internet as a central phenomenon of contemporary modernity that interacts with practiced fundamentalist religious traditions. We ask how broad the interactions are between religious fundamentalism and the Internet and whether these relations can be reconciled. More specifically, we present a comprehensive study of the junction of IT and religious fundamentalism among ultra-Orthodox Jews, in order to demonstrate how the Internet has been culturally constructed, modified and adapted to the community's needs and how the Jewish fundamentalist community has been affected by it.

Religious fundamentalism is a system of absolute values and practiced faith in God that firmly relies on sacred canonical texts. A significant level of affinity among its members, seclusion from the world that surrounds it, strict communal discipline and a patriarchal hierarchy often characterize it. Conversely, cyberspace is perceived as a reflection of contemporary rationale and scientific modernity. For many observers, the virtual space symbolizes individual freedom, inclusiveness, socioeconomic mobility, egalitarianism, and even a chaotic space of infinite, multifaceted, interactions among individuals and groups (Castells, 2000, , DiMaggio et al., 2001, , Kling, 2000, , Fisher and Wright, 2001). Religious fundamentalists apparently view modernity as a heretic concept and they can be regarded as a reaction to modernity (Marty and Appleby, 2004, , Marty and Appleby, 1991). As we show below, religious fundamentalist communities are suspicious of technology and 
cyberspace in particular, because they see it as a threat to the cultural preservation of their community.

In this article we identify four principal dimensions of religious fundamentalism as they interact with the Internet: hierarchy, patriarchy, discipline and seclusion. We are interested mainly in the interchanges between these two phenomena, both of which are related to modernity yet profess to be antithetical spaces of prominent human activity (Dawson 2004). More specifically, we analyze how social discipline and confined individual freedoms within religious fundamentalist communities are reconciled with modern, largely secular, telecommunication technologies. Finally, we develop the concept of cultured, i.e., socially constructed, technology.

Katz and Aakhus (2002) argue that it is technology that predominantly influences human life. They denote the process as apparatgeist, i.e., "a new term to describe social change and its interactions with social institutions within the technical communication context" (Katz and Aakhus, 2002, 304). According to them, in late modernity, it is technology that shapes history. In their study, Katz and Aakhus refer to three aspects of apparatgeist: First, the "perpetual contact" among human beings enabled by mobile technologies reshapes boundaries between private and public spheres. Second, human beings relate to technology not only on the basis of its everyday functionality, but also by embracing values and contents that are promoted through the ethos of perpetual contact. Third, even those who wish to evade, ignore, or even struggle against technology, are profoundly affected by it. Although we accept Katz and Aakhus's three basic claims, which are based on their study of mobile phones, our research and main arguments differ significantly.

Contrary to Katz and Aakhus, in our study we find no unified and objective apparatgeist that imposes itself invariably on all cultures. (For a similar argument about the diversity of technology, see Dawson and Cowan 2004). Following a systematic analysis of the literature and an empirical examination of a religious fundamentalist community, we advance the following argument: cultural spaces that initially resist technological modernity vigorously, are affected by the Internet by means of complex communal processes that adapt the Internet to fulfill their fundamentalist religious needs and in the process transform it into a new and different type of technology that suits their community. We find that cultures 
modify technologies and endow them with a communal context. The Internet thus becomes a set of varied cultured technologies in different cultural contexts.

More specifically, we argue that Internet applications are subject to cultural modifications and localization processes through networks, discipline and regulations within various local communities. These processes work two ways: while the community localizes the technology, the community itself is reshaped to become a part of a globalized world. Cultured technology becomes a requirement for religious fundamentalist communities in order for them to exist within their traditional internal and external boundaries. We argue that the extent to which technology can be culturally modified creates opportunities for community members to express themselves.

The next section presents a theoretical and comparative analysis of four dimensions of possible conflicts and symbiotic relations between the Internet and religious fundamentalism. We then present an analysis of an actual case study of the Jewish religious fundamentalists in Israel, the ultra-Orthodox, which is based on empirical evidence drawn from primary and secondary sources.

\section{When Cyberspace Encounters Religious Fundamentalists:}

\section{A Theoretical Outline}

Religious communities preceded the nation-state and are denoted by various scholars of politics of identity as the oldest form of identity groups (Gutmann, 2003, 151). In popular culture, the term religious fundamentalism often denotes political extremism, violence, and terrorism. However, we are dealing with much broader aspects of religious fundamentalism. On a fundamental level, religious fundamentalism is essentially an ultraconservative approach to religious texts through an attempt to avoid pragmatic compromises with modernity. Hence religious fundamentalism may be perceived as a reaction to modernity aimed at preserving religious values against modernity's secular temptations (Marty and Appleby, 1993, , Marty and Appleby, 1991).

Based on the above definition, ultra-Orthodox Jews are fundamentalists (Friedman, 1991, , Liebman, 1993). While the literature shows that, under certain circumstances, offline communities may also be online communities (Etzioni, 2003, , Wellman et al., 2002, , 
Dawson, 2001), the interaction between online and offline communities among religious fundamentalists is much less evident. Lorne L. Dawson (Dawson, 2001, , Dawson, 2000, , Dawson, 2004 forthcoming) forcefully argues that since there is little literature on religion and the Internet, scholars need to better understand the shaping of religious identities and religious communities online.

Below we have outlined four dimensions that define the sociopolitical features of religious fundamentalist communities in context of their interactions with the Internet. This theoretical outline enables us to comprehend the meaning of the Internet as a cultured technology.

\section{A. Hierarchy: First Dimension of Tension}

Religious fundamentalist communities are characterized by a tight hierarchy (Barzilai, 2003, , Weber, 1964 (1922), , Liebman, 1993). The religious communal hierarchy is based mainly on the subordination of large groups to an elite religious authority that often professes the bestowal of divine authority. Examples include the Ulama in Islam, the Rabbi in ultraOrthodox Jewish communities, the Bishop and the Priest in Christian and Buddhist congregations. As Max Weber pointed out, hierarchy is based on the divine authority of a charismatic figure, and on his ability to consolidate legitimacy and to generate obedience through and for religious faith (Weber, 1946, , Weber, 1947). The concept that modernity necessarily secularizes human society and consequently weakens religious hierarchies, as was suggested by Emile Durkheim (Pickering, 1984), is too simplistic and largely erroneous, as we argue and demonstrate in this article.

Hierarchies constitute and are based on elites that control the flow of information (Bachrach and Baratz, 1970, , Lukes, 1974, , Jasperson et al., 2002, , Pfeffer, 1994). Customarily, channels of communication within religious fundamentalist communities are vertical, since the main source of information is the religious dicta funneled from the elite to the subordinates (Spigelman, 2000). Censorship is a major means by which the communal elite control information flows (Edelman, 2002, , Machlis, 2003, , RSF, 2003, , Peled, 2000). Censorship is imposed on the Internet by either a-priori or posteriori means (BarzilaiNahon, 2004). A-priori censorship, which aims to restrict availability and accessibility to information resources, is exercised through mechanisms such as blocking, filtering, zoning and control of the network infrastructure. In some communities, like the Amish or very conservative Muslim communities, accessibility to the Internet is simply prohibited and no 
appropriate technological infrastructure is made available to the community (Hostetler, 1993). On the other hand, censorship may also be exercised using posteriori mechanisms, such as deletion of information after it has been posted on the web or the infliction of punishments on transgressors. Religious elites are fearful of losing control over the information flows within the boundaries of their communities, because in their view, the Internet poses a threat to the community's culture and challenges their legitimacy.

Even the most isolated and closed communities cannot prevent their members from frequenting the cyberspace. Studies show that members of even the most orthodox communities use the Internet worldwide for various purposes, ranging from e-commerce, requests for information, entertainment, debates, virtual pilgrimages, dissent against their own community and social engagement with outsiders (Spigelman, 2000, , Dawson, 2001, Dawson, 2000, , Dawson, 2004 forthcoming, , Dawson and Cowan, 2004 forthcoming, , Hojsgaard and Warburg, 2004 forthcoming, , Rafaeli and Sudweeks, 1998). As we will show later, these cyber-activities are not taken "as is" from the secular world. IT and information are transformed and modified through processes of localization ${ }^{1}$ to adapt to the specific characteristics of the different communities. Even under the harshest conditions of communal surveillance, individuals find ways to circumvent censorship, access forbidden material $^{2}$ and employ applications that might contrast and challenge the community's character and basic principles.

Technology, and specifically the Internet, serve the hierarchical realm well by means of personalization and contextualization tools (Barzilai-Nahon, 2004). For example, the elite may utilize various technologies and information systems to disseminate personalized information to targeted users for purposes of communal socialization and mobilization. The community is able to affix the hierarchical order online, not less than offline, by offering its

\footnotetext{
${ }^{1}$ Localization means adapting a technology product or service (including its software, documentation and related material) to a specific culture. This also includes making sure that graphics, colors, sound effects, terms and relevant items such as dates, calendars, measurement units, monetary notations and legal procedures are in the correct format and context and are culturally appropriate.

${ }^{2}$ For example, accessing forbidden material may be done through using remote proxies and anonymous remailers. Circumvention occurs also while using mechanisms that belong to the community itself, since mechanisms of blocking and filtering have their own technological deficiencies and may be by-passed by savvy users.
} 
members virtual services (e.g., e-prayers and online consultations with higher religious authorities) that before the Internet were available only face-to-face. A report by Pew Internet \& American Life Project provides another example of how the Internet serves the religious hierarchy. Most of the 1,309 congregational respondents said that the elites "are eager to use their Web sites to increase their presence and visibility in their local communities and explain their beliefs. They are much more likely to use the Web for oneway communication features such as posting sermons or basic information about the church, rather than two-way communications features or interactive features such as spiritual discussions, online prayer, or fundraising" (Larsen, 2000, 2).

The two main Internet applications used by the religious elite are e- mail communication among the ministers (91\%), and mobilization- $-83 \%$ of the respondents use the Internet to encourage visitors to attend their church, and $77 \%$ utilize it to post mission statements and sermons. The benefits reaped by the elites by allowing Internet access far outweigh the costs in terms of loss of some control, especially when the usage of Internet applications is strict and confined (Tonn and Ogle, 2002, 3). Thus the community may use Internet and still maintain its original institutional patterns of hierarchy. In general it may be said that religious fundamentalist communities are a part of the globalization process, being tied to it, inter alia, through the usage of the Internet. At the same time, however, they continue to preserve their power structure.

Each Internet application provides a different type of communication. Consequently, community members participate in various forms of communal discourse. For example, applications that provide platforms for the simultaneous interaction among many users (i.e., forums and newsgroups) are more likely to facilitate the entry of exogenous forces into the community and the exit of members from it. Based on the arguments of other scholars (Hampton, 2001, , Wellman, 2002, , Robertson, 1995), we assert that through IT there is a possibility of glocalization ${ }^{3}$ in religious fundamentalist communities. In this context, glocalization means a process by which the global is selectively and partially injected into

\footnotetext{
3 "Glocalization is described as the growth of social capital, locally and with ties at a distance, as a result of computer-mediated communication" (Hampton, 2001, p.6; for the general term see Robertson, 1995).
} 
the local, whereby the hierarchy may be weakened but is still preserved. To summarize, the Internet can be culturally constructed in ways that adapt it to the needs of a religious fundamentalist hierarchy.

\section{B. Patriarchy: Second Dimension of Tension}

Findings show that women may use the Internet to voice disputes with the patriarchal hierarchies in their fundamentalist religious communities, all the while remaining loyal to their community culture and discourse (Bastani, 2000). For instance, women use the Internet to gather and disseminate information online. They thus employ the Internet to enhance their studies of women's history, science, and philosophy. ${ }^{4}$ An example of such an activity is SisterSite, ${ }^{5}$ a website that serves religious fundamentalist communities and aims to disseminate information on women's religious congregations, the history of religious life from a feminine perspective, and the contemporary concerns of religious women. Some websites focus on Catholicism, but they also attempt to serve the needs of members of other religions. In addition to Internet sites that serve women as information tools, there are sites that nurture online interactions among them (e.g., women spirituality, community-building and women experience $)^{6}$ by means of discussion groups and listserv applications, rather than passive interactions.

One can find Islamic fundamentalist "mothers and housewives", from Egypt, Iran, Saudi Arabia, the West Bank and Gaza, who exchange ideas online "through America Online Islam chat rooms and messaging boards, through MSN Islam message boards and, just like anyone else, through e-mail. They talk about their children, perfecting their relationship with Allah (Shahada) [...]"(Ramos, 2002). Nevertheless, in their online communication, these women emphasize their obligation to motherhood and being 'good' women.

The Internet usages that are mentioned above show online activities as complementary to life offline in religious and even fundamentalist communities. Lately, we see a growing number of cases where women use the Internet to escape online from their offline religious communities. In some instances they even form alternatives to the existing inner rules of

\footnotetext{
${ }^{4}$ For example: Women and Religion, http://gaelnet.stmarys-ca.edu/study/religion/women.html, accessed November $1^{\text {st }} 2003$.

${ }^{5}$ SisterSite, http://www.geocities.com/Wellesley/1114/, accessed November $1^{\text {st }} 2003$.
} 
their fundamentalist communities. For example, the Revolutionary Association of Women of Afghanistan (RAWA) ${ }^{7}$ is the oldest political and social organization of Afghan women struggling for democratic rights and against the fundamentalist Taliban in Afghanistan. Using the Internet to foster Halachik (biblical and Talmudic) studies by Jewish women, ${ }^{8}$ a practice often restricted inside Jewish ultra-Orthodox communities, is another instance of behavior empowered by and through the Internet. The Internet is used within religious fundamentalist communities as a means of communication, among each other in the community or with the outside world, which transcends the boundaries imposed by the religious patriarchic hierarchy in the community. Religious women use the Internet to surpass somewhat the limitations imposed upon them in their personal and public life. Hence, the Internet, to some extent, serves as a communal means of feminization and emancipation, even in the fundamentalist religious context.

The literature on the gender-based digital divide is fuzzy. On the one hand there are those who claim that the digital divide between men and women exists (Goulding and Spacey, 2002, , Bimber, 2000, , Hoffman et al., 2000, , Ono and Zavodny, 2003), while on the other hand, there are those who argue that the gender gap does not exist (Lebo, 2003, , Glasner, 1999). Recent studies conclude that a gender gap does exist, but not in terms of access but rather in terms of frequency and intensity of use: "Women were significantly less likely than men to use the Internet at all in the mid-1990s, but this gender gap in being online disappeared by 2000 . However, once online, women remain less frequent and less intense users of the Internet." (Ono and Zavodny, 2003, 1). Glasner (1999) also admits that "According to Web audience measurement firm Nielsen/NetRatings, 49.5 percent of all Internet users in the United States are women." ... "Recent statistics also show that women don't usually spend as much time online as men."

It seems that the Internet has not revolutionized religious fundamentalist communities, since women's accessibility, as well as the frequency and intensity of Internet usage, are more confined compared to men (Ramos, 2002). Although cyberspace has emancipated women

\footnotetext{
${ }^{6}$ Women's Spiritualities, http://www.clas.ufl.edu/users/gthursby/mys/womens.htm, accessed November $1^{\text {st }}$ 2003.

${ }^{7}$ RAWA, http://rawa.fancymarketing.net/, accessed January $15^{\text {th }}, 2004$.

${ }^{8}$ Women and Judaism, http://www.earlham.edu/\% 7Elibr/acrlwss/wsstheo.html\#judaism accessed January $15^{\text {th }}, 2004$.
} 
somewhat from their inability to transcend their local communal boundaries, in most cases, cyberspace is not perceived as an alternative to religious communal life. Rather, it is perceived as a platform to communicate within and outside the community in ways that empower feminine identity. In conclusion, we assert that the Internet has created better opportunities for feminine voices to be heard in religious fundamentalist contexts, although these opportunities are framed within the communal context and its hierarchy. Cultured technology mitigates the possible conflict between feminism, religiosity and community.

\section{Discipline: Third Dimension of Tension}

Fundamentalist religious communities are highly disciplined, their behavior being based on sacred texts and the hermeneutics that surround them (Barzilai, 2003, 209-278). The term fundamentalist means that these communities strive to preserve the original meaning of their texts with as few adaptations to modernity as possible. Discipline is perceived as the only alternative to blasphemy. A significant change is possible only if the spiritual authorities define a path of hermeneutics that legitimizes it. The discipline is embedded in the collective consciousness through spiritual authorities, law, systems of learning and education, the family and daily practices (Spigelman, 2000). It is neither merely a certain formal dimension, and nor solely a textual phenomenon. Rather, it is a set of practices and a consciousness that exist anywhere and anytime in communal life. That socio-political-legal apparatus of discipline may be hostile to the Internet (Boyarin, 1997, , Hostetler, 1993, , Asad, 1993). Since modernity is perceived in religious fundamentalist communities as contemporary secularism, punishments and technologies of censorship are imposed against impermissible expressions (Privacy International and GreenNet Education Trust, 2003). The religious texts are the formative constitutional texts of the community, and hermeneutics that are not legalized by the communal authorities are completely prohibited. However, the Internet, as described below, may be a way to evade such prohibitions despite the tight hierarchy, patriarchy, and discipline.

Landow and Delany (1991) refer to the printed text as linear, bounded, structured in a certain logic, and fixed. Wills (1999) notes that "it has a particular focus, a clearly-defined audience and a single voice"... "Another tenet of the print medium has been the creation of the canon: the chosen texts are assumed to contain the central authoritative 'truths' of a discipline. By staying available in print, these retain their central role" (Wills, 1999, 134). 
These characteristics are certainly valid with regard to religious printed texts that enjoy the status of reflecting an authoritative, divine and canonical truth.

While printed religious texts direct the believers to look inward into the community, and to foster the preservation of the textual tradition, technological innovations enable intensive interactions that cross the rigid boundaries of the community itself. Hypertext links information through associations and not sequentially and is powered by hyperlinks, which allow the reader to skip to another location on the web. Hypertext, therefore, breaks traditional hierarchy among texts and "seems to confirm the critical notions about the elusive boundaries between texts and the questionable authority of authors" (Wills, 1999, $135)$.

Contrary to printed texts, Hypertext is interactive, non-linear, associative, not-fixed, modular, and not necessarily owned by an identified single author. Hence Hypertext may be said to repudiate discipline by transferring the power of presenting religious texts from the spiritual authorities to the subordinates, the users. Consequently, telecommunications as such may incite significant suspicions in the context of communal discipline. Moreover, the Internet may directly challenge the disciplinary constraints imposed on the religious fundamentalist community by allowing and opening new prisms of interpretation to dicta imposed by the fundamentalist community.

No religious community can entirely escape the presence of the Internet (Dawson, 2001). Furthermore, the same technology that is perceived as a threat to the existence of fundamentalist communities may be viewed as a force that enhances their cohesiveness. "We believe this technology, which allows combination of different media (text, sound, pictures) and an arbitrary interconnection of elements to form 'hypertexts', has properties rich enough to support the construction of a community's story" (Beeson, 2002, 644). This may be done, for example, by using Internet applications that enable many people to share in the narratives of the community at the same time, e.g. forums or newsgroups.

Similar to our discussion of patriarchy, here too, the Internet can be culturally constructed in ways that adapt it to religious fundamentalist discipline. Many religious fundamentalist communities that are present on the Internet enhance their communal discipline by using applications such as discussion groups, Intranets, listservs, chats, and forums that enable 
collaboration by many users to empower the communal consciousness. These applications do not necessarily infringe upon communal discipline. Rather, they consolidate discipline in cases where the community is polarized, fragmented, or when there are various segments in the diaspora (Wellman, 2002). In that sense, the Internet has become a significant element in the communal social capital, for good and for bad (Putnam, 2000, , Wellman, 2001, , Burt, 2000). We assert that despite the strong effects of discipline on life in religious fundamentalist communities, the Internet is certainly capable of penetrating these communities, as long as it is culturally constructed.

There are many examples of how the Internet assists in the maintenance of communal religious discipline, mainly by preserving basic cultural attributes. Studies about Islamic cyberspace show how Islam has been extensively enhanced on the Internet (Adamu, 2002, , Bunt, 2003). Numerous sites promote traditionalist studies of Islam (Adamu, 2002). The Muslim scholar of Islam, Abdalla Uba Adamu, relates: "One indicator of the potential transformational qualities of the Internet on Muslims is the presence of a broad range of 'sermons' on-line." For example, Tanzeem-e-Islami's ${ }^{9}$ in Pakistan presents a selection of recorded sermons for downloading. Other platforms that create on-line sermons for consumption by an international audience include the Taliban, Khutbah Online ${ }^{10}$ and AlMuhajiroun. ${ }^{11}$

With regard to other religions, the Pew Internet \& American Life Project reports that studies of various religious communities in the US indicate that about 82 million Americans (64\% of American users) use the Internet for religious purposes (Hoover et al., 2004). ${ }^{12}$ Another study (Larsen, 2001) reports that “...81\% of Religion Surfers describe their religious faith as 'very strong,' compared to $61 \%$ of the general public who said in March 2000 Gallup poll that religion was very important in their life" (Larsen, 2001, 3). More intriguing is the following conclusion: “.... it is interesting to note that more people have gotten religious or spiritual information online than have gambled online, used Web auction

\footnotetext{
${ }^{9}$ Tanzeem-e-Islami's, http://www.tanzeem.org.pk, accessed January $15^{\text {th }} 2004$.

${ }^{10}$ Khutbah Online, http://dar-us-salam.com/khutba, accessed January $15^{\text {th }} 2004$.

${ }_{11}^{11}$ Al-Muhajiroun, http://www.almuhajiroun.com, accessed January $15^{\text {th }} 2004$.

${ }^{12}$ In 2001 only 28 million Americans were reported using the Internet for religious purposes. See: (Larsen, 2001)
} 
sites, traded stocks online, placed phone calls on the Internet, done online banking, or used Internet-based dating services"(Larsen, 2001, 2).

Another such report (Larsen, 2000) informs us that $83 \%$ of the congregations that participated in the study reported that their Web sites and use of e-mail contributed to the spiritual life of the congregation, "some or a lot." (Larsen, 2000, 21). Indeed, these surveys do not differentiate between fundamentalist communities and other believers, but it is clear that, in general, the Internet has inter alia become a religious services provider in the US. This may explain why, according to the report, the most active online religion surfers are also the most active members of their offline religious congregations (Larsen, 2000, 3).

Communal discipline in religious fundamentalist communities may have negative repercussions, since peripheral groups, such as extremely violent fundamentalist groups like the Hamas, Hizbollah, and AlQuaida, may exploit the Internet to coordinate various illegal operations and to overcome territorial boundaries (Davis, 2003, , Rozen, 2003, , Bunt, 2003). For example, the Internet is used as a propaganda tool by Hizbollah, which manages three web sites - one for the central press office, ${ }^{13}$ another to describe its attacks on Israeli targets, ${ }^{14}$ and a third for news and information. ${ }^{15}$ To the same degree, religious Satanic communities and other forms of new religions use the Internet massively in order to consolidate their communities (Perlmutter, 2002, , Dawson and Hennebry, 1999).

\section{Seclusion: Fourth Dimension of Tension}

The dimensions analyzed above raise the question as to what extent the Internet actually reduces the seclusion of religious fundamentalist communities. Recall that according to research on communities, their seclusion and the cultural boundaries that surround them are part of their collective identities as communities (Barzilai, 2003). As a matter of fact, the scope of seclusion may be enhanced through the Internet rather than reduced. For example, The Pew Internet \& American Life Project study (Larsen, 2001) reports that most religious surfers $(67 \%)$ use the Internet to gather information about their own faith and not to learn about other religions.

\footnotetext{
${ }^{13}$ Hizbollah, http://www.hizbollah.org/, accessed January $15^{\text {th }} 2004$.

${ }^{14}$ Islamic Resistance Support Association, www.moqawama.org, accessed January $15^{\text {th }} 2004$.
} 
Communities modify and localize technologies in ways that preserve the community's seclusion. They may force their members to interact only through inner-community Internet platforms, avoid any usage of secular platforms and limit access to only appropriate information sources inside the community (Dawson, 2001). It enables them to "protect" their communities from external cultural transplantation.

Simultaneously, erosion of seclusion may occur when the community starts preaching its faith to others, or when non- members try to become integrated into the community. Both these types of interactions can be facilitated through the Internet. In Islamic communities, the Internet is utilized to spread the religion beyond its boundaries (Adamu, 2002). In turn, such an expansion invites more plurality inside the community, in ways that make the collectivity more open to internal dissent and controversies despite the communal hierarchy and discipline. Scholars of Islam, for example, have shown that the Internet has incited more controversies among religious communities about interpretations of the Qua'ran (Adamu, 2002).

The expansion of the community through IT also increases its transparency to the general public. For example, once these communities are on the net, statistics and other information regarding their online behavior can be gathered and analyzed. Therefore various identity groups may generate more secular pressures on the community. Additionally, members of the community may use the Internet anonymously in platforms that are not supported through their communities (Lee, 1997). It permits them to reach alternative content that may be unacceptable in their own religious context. Hence, while the Internet is culturally constructed in the communal context, it still may reduce seclusion both inside and among communities.

The analysis of hierarchy, patriarchy, discipline and seclusion highlights the major practical and potential tensions between religious fundamentalist communities and the Internet. Our comparative and theoretical analysis defines the scope of a global challenge that transcends national and geographic boundaries.

15 Almanar, www.almanar.com.lb, accessed January $15^{\text {th }} 2004$. 


\section{Faith in Cyberspace: Ultra-Orthodox Jews as an Online Community}

\section{Background and Methodology}

In this section we examine the ultra-Orthodox Jewish community according to the four dimensions explicated above. The examination includes primary and secondary data, supported by literature review. The secondary data analysis relies on data provided by the Israeli Central Bureau of Statistics. Primary data was collected via the platform of a virtual community enabler in Israel named Hevre, and includes a rare dataset of about 686,000 Israeli Internet users. Dror (2003) estimates that $20 \%$ of the ultra-Orthodox use the Internet (around 80,000 users). In this rare dataset, we were able to identify and analyze the characteristics of about 14,000 ultra-Orthodox surfers. Hevre is a virtual community enabler business in Israel, similar to the American concept of ClassMates. ${ }^{16}$ Hevre enables offline organizations, groups and communities, such as high schools, elementary schools, academic institutions, military units and work mates to have their own virtual communal space on the Internet, by supplying them with value added services. Each online community can utilize services such as forums, e-mail, SMS, voice messages, links, gossip topics, individual profiles, photo albums and more. Contrary to other community enablers on the Internet, the members of Hevre identify themselves. They are not anonymous and the y do not use pseudonyms. Moreover, these online communities exist only as part of physical offline communities. Namely, in order to be associated with your community online, you need to disclose many personal details, such as age, religion, occupation, address, marital status, gender and more. These details are verified during the subscription process and during the user's stay in the virtual community.

For the purpose of this study, we programmed applications to extract relevant data from Hevre's information systems. The dataset originally included one million users. We excluded observations of users who could not be affiliated with any particular identity group (i.e., ultra-Orthodox, religious, seculars), and of users whose profile was missing some characteristics. ${ }^{17}$ Consequently, the dataset contains 60,346 different online communities and 686,000 users, and is separated into secular, religious and Jewish fundamentalists (ultraOrthodox) in Israel. Through our analysis of the original dataset, the secondary data, and the literature, we were able to observe how Jewish fundamentalists use the Internet, and how

\footnotetext{
${ }^{16}$ Classmates.com, www.classmates.com, accessed October $27^{\text {th }} 2003$.

${ }^{17}$ Users were classified according to address, occupation, and affiliation in an identified community.
} 
they act as a virtual community while utilizing non-religious Internet applications and technologies.

Ultra-Orthodox Jews constitute about 6\% of Israel's population (Gaist, 2003). Most of them live in two cities: Jerusalem and Bnei-Brak. Historically, they were the majority among the Jewish population around the world. Gradually, after the Enlightenment in the $18^{\text {th }}$ century, the emergence of Zionism in the $19^{\text {th }}$ century, and following the Holocaust (1939-1945), Jewish culture and demography changed. Majority of Jews around the globe underwent secularization from the 18th century onwards and were assimilated into the general population. During WWII, the Nazis annihilated most of the ultra-Orthodox communities, primarily in Central and Eastern Europe. Ultra-Orthodox Jews are easily identifiable since most of them preserve the dress and the religious fundamentalist way of life of old Europe.

The ultra-Orthodox community is very tightly organized around the strict observance of the Halacha, i.e., the Old Testament and the Talmud that are preserved as the supreme and ultimate guiding texts to direct the life of the community. They differ from the secular westernized public and from the religious Zionist public in their dress and the daily practices that are aimed at isolating the community from its 'heretic' surroundings (Boyarin, 1997, , Friedman, 1991, , Liebman and Katz, 1997). The Halachic hermeneutics are so fundamentally preserved that only minimal compromises with modernity are allowed, if at all. Ultra-Orthodox Jews live differently from birth to death and are isolated from the general society. Like the Amish and Islamic communities, ultra-Orthodox Jews have an autonomous system of education from the age of 2-3 years, where Halachic studies are the major component of the curriculum at the expense of other subjects such as humanities, mathematics, computers and science. Let us now examine the ways the community has constructed the Internet in face of the serious challenges posed by each of the dimensions.

\section{A. Hierarchy: First Dimension of Challenge}

The formal interpretations of Halacha as the prime source of legal obedience are rendered exclusively by the spiritual authorities of the community, mainly the Rabbi(s) and the Dayanim (judges). In the 1990s, a proclamation, signed by most of the leading ultraOrthodox rabbis, was issued warning against the danger of having Internet at home. Similar to the prohibition of having TV sets at home, the spiritual authorities defined the Internet as a dangerous technology since it may expose the users to the blasphemy of modern 
secularism. Thus the Internet is formally prohibited in the Jewish fundamentalist community (Rosenblum, 2000). In some places it is allowed when it is for work purposes (Schechter and Ser, 2000). In practice, however, things are somewhat different.

While TV sets are not indispensable for daily practices, e.g., in the job market, the Internet is useful for various daily activities, from consumption of information to professional activities and commerce. Hence, it has affected the religious fundamentalist community, despite fervent formal Halachic hostility. Gradually more and more ultra-Orthodox use Internet in spite of formal prohibition. Based on our dataset, Graph 1 below exhibits the existence of ultra-Orthodox Jews on the Internet and compares it with the total population. ${ }^{18}$

\section{Graph No. 1: Internet Users vs. Population Distribution (in percentages)}

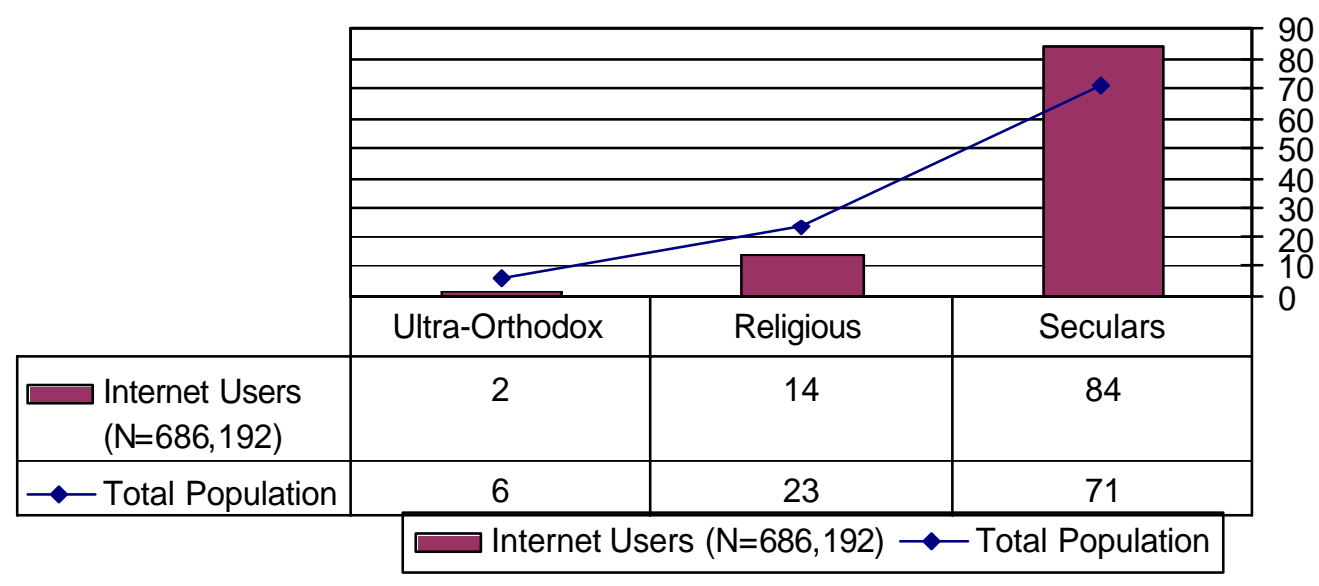

Taking into account the fact that our figures relate to virtual participation of religious fundamentalists on a secular platform, the numbers are certainly surprising considering the frantic Halachic suspicions of technological innovations.

The gap between religious fundamentalists and the general population is even more evident in comparisons based on Internet subscriptions per household and the number of personal computers per household. Based on data from the Israel Central Bureau of Statistics (Heller, 2002, , Heller, 2000, , Heller, 2001), we can see in Table 1 that in Bnei-Brak, a major ultraOrthodox city, religious fundamentalists do use the Internet. The fact that about $37 \%$ of the households in Bnei-Brak have personal computers demonstrates that the intrusion of

\footnotetext{
${ }^{18}$ Data on the general population was taken from the Israeli Central Bureau of Statistics, 2003.
} 
telecommunications into the last bastions of opposition has become a reality. Yet, the percentage is far smaller than that for the overall population, mainly due to formal Halachic opposition to cyberspace and the restriction on the possession of a personal computer unless it is for professional purposes. Since the spiritual authorities are inclined to allow Internet access exclusively for professional use, only a small percentage (about 6.4\%) is connected to the Internet from their private home. Inside the community, where surveillance and hierarchy of the spiritual authorities exists, the scope of connection to the Internet in private households is limited compared to the overall population.

Table No. 1:

PC Ownership and Internet Subscription in Large Cities ${ }^{19}$ (in percentages)

\begin{tabular}{|c|c|c|c|c|c|c|}
\hline Bnei- Brak & $\begin{array}{c}\text { Rishon } \\
\text { Lezion }\end{array}$ & Haifa & Tel-Aviv & Jerusalem & Avg. & \\
\hline & & & & & & 2002 \\
\hline 37.5 & 67.4 & 51.6 & 57.1 & 51.0 & 53.8 & PC ownership \\
\hline 6.4 & 37.9 & 28.9 & 33.2 & 20.2 & 25.4 & Internet Subscription \\
\hline & & & & & & 2001 \\
\hline 29.1 & 61.6 & 50.0 & 47.6 & 48.0 & 49.9 & PC ownership \\
\hline 3.0 & 33.9 & 24.5 & 28.6 & 19.0 & 22.5 & Internet Subscription \\
\hline 34.0 & 63.9 & 51.1 & 45.5 & 50.0 & 47.1 & PC ownership \\
\hline 7.4 & 28.8 & 24.6 & 25.8 & 20.7 & 19.8 & Internet Subscription \\
\hline & & & & & & 1999 \\
\hline 28.2 & 57.2 & 38.7 & 42.1 & 34.5 & 40.7 & PC ownership \\
\hline 3.5 & 17.9 & 13.6 & 14.1 & 10.0 & 11.9 & Internet Subscription \\
\hline & & & & & & \\
\hline
\end{tabular}

The usage of secular platforms outside the scope of the communal hierarchy, however, is much broader and is done through public Internet access sites or private computers located outside the community. As seen in Graph 1, above, ultra-Orthodox users of secular platforms comprise about one third of the entire ultra-Orthodox population, which is higher than many estimations.

\footnotetext{
${ }^{19}$ Data is based on the Israeli Central Bureau of Statistics (Heller, 2000; Heller, 2001; Heller, 2002).
} 
Incrementally, the spiritual authorities have had to adapt to the changing reality and to allow some connection between community members and the global process of expanding telecommunications that has become an integral to the modern economy (Rebibo, 2002). The alternative to Internet adaptation would have been even graver poverty in a community where most of its male members (about 70\%) devote all their time to learning Halacha in $a$ Yeshiva (Rebibo, 2002). Consequently, prominent spiritual leaders issued numerous Halachic proclamations allowing members time to acquire professional-even academictraining in computer programming and other technological fields. In February 2003, Cisco started computer telecommunications training for ultra-Orthodox in Jerusalem and BneiBrak, as part of Cisco's global Networking Academies (Rebibo, 2002). It is an expression of how international capitalism and its expansion through IT has affected even ultra-Orthodox authorities that have come to consider computerized telecommunications a necessity for solving economic predicaments. However, Internet usage for other purposes is still banned. The Internet, in ultra-Orthodox society, has been culturally modified to fit the context of its communal needs and structure.

Moreover, among the educated, the Internet has been absorbed to some extent (see Graph 2). Our dataset indicates that there is a significant correlation $(\gamma=0.364)$ between education and Internet usage. Ultra-Orthodox users have more formal education than secular and religious users. The results are strongly significant $\left(\chi^{2}=11,250, \alpha<0.001\right)$.

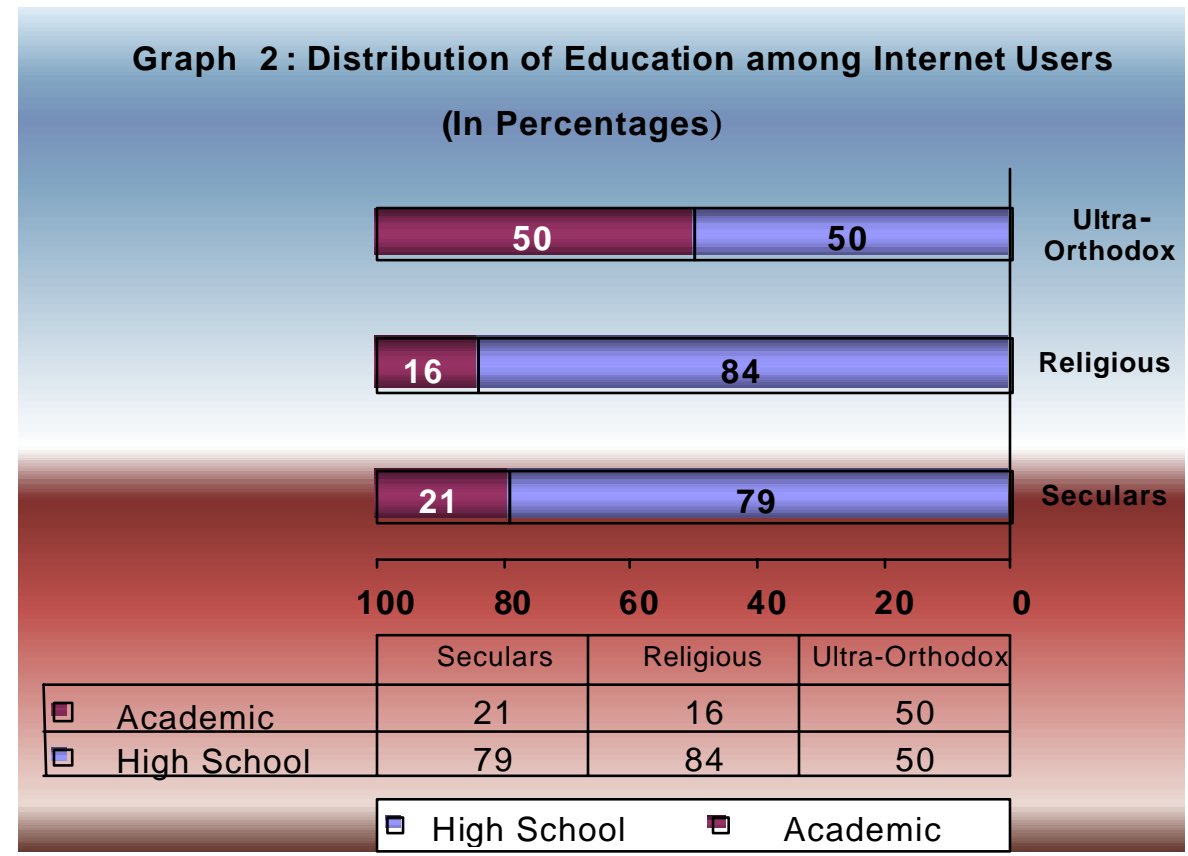

$$
\left(\gamma=0.364, \chi^{2}=11,250, \alpha<0.001, N=686,220\right)
$$


The same phenomenon of hierarchical usage is evident when we measure the socioeconomic status of Internet users. We measured socioeconomic status through three variables: occupation, user's shopping history in the Internet and level of education. This kind of measurement provides us with the most accurate information about the user's social class. Graph 3 below shows the socioeconomic status of the three relevant sectors.

\section{Graph 3: Internet Users' Socioeconomic Status (in percentages)}

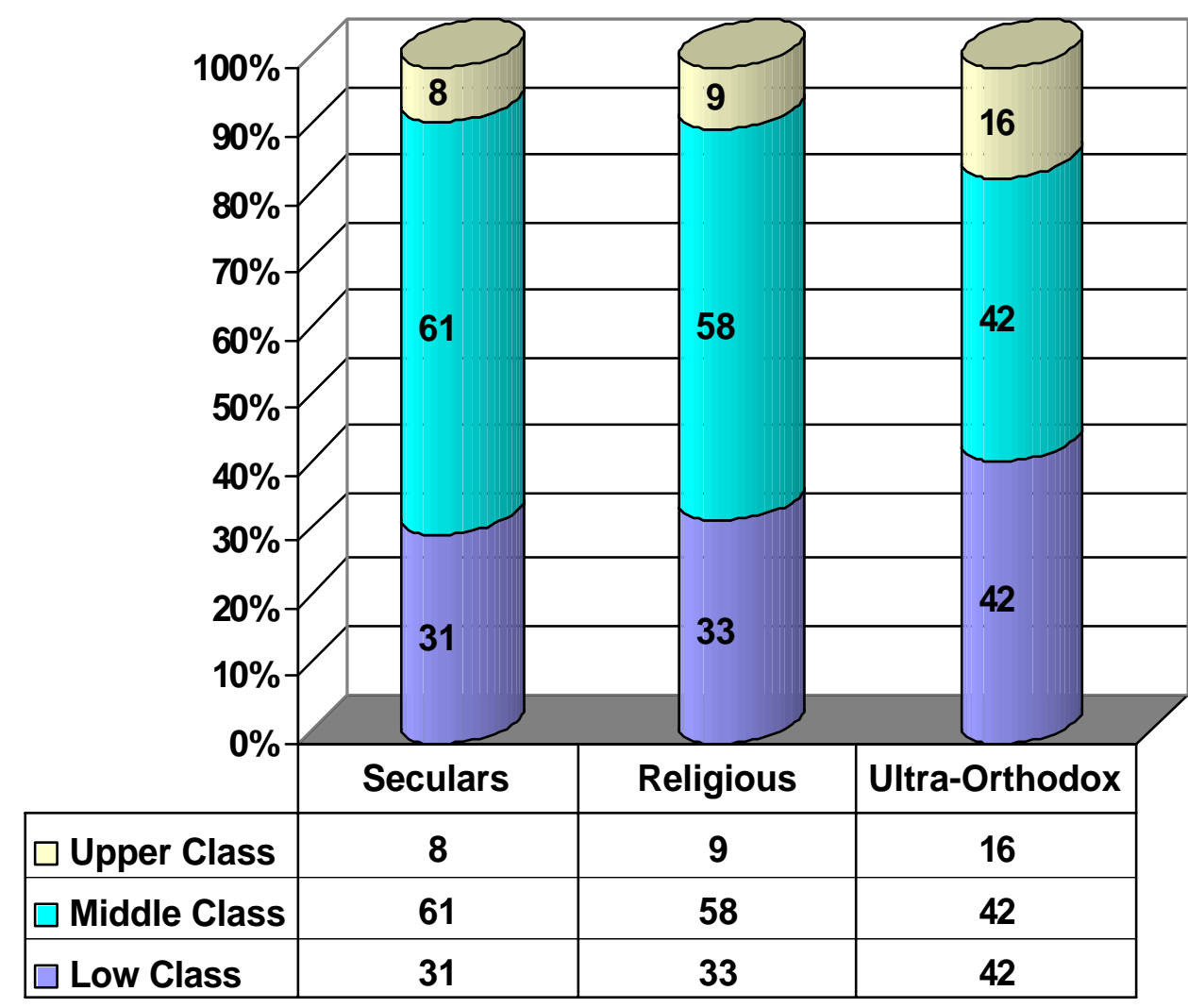

\section{Low Class $\square$ Middle Class $\square$ Upper Class}

$$
\left(\gamma=\mathbf{- 0 . 0 2}, \chi^{2}=\mathbf{2 5 8 1}, \alpha<0.001, \mathrm{~N}=\mathbf{6 7 7 , 5 4 3}\right)
$$

Evidently, there is no direct ordinal correlation between the level of religiosity and the socioeconomic status of Internet users. Therefore, the $\gamma$ coefficient is very low.

Nevertheless, since the statistical analysis is significant for the whole population $(\alpha<$ 0.001), we can infer that the percentage of upper social class users among ultra-Orthodox is larger than among the secular and the religious. Surprisingly we find that the digital divide among the online ultra-Orthodox is smaller than the divide among religious and secular 
users. Thus the lower and middle class among ultra-Orthodox users are equal (42\%), while the percentage of the middle social class among religious and secular users is larger, indicating that the lower social class among secular and religious users is still mostly offline. As can be seen in Graph 3, once ultra-Orthodox Internet users communicate using secular platforms, hierarchical influence is rather limited as far as socioeconomic status is concerned.

Conversely, the majority of web sites regulated by the ultra-Orthodox is intended to preserve and strengthen the communal hierarchy and are tightly supervised by the spiritual authorities. These web sites are designed for disseminating religious texts and religious information $^{20}$ or to counter arguments raised by political foes against the community. Examples are a web site meant to defy criticism against the exemption of Yeshiva students from compulsory military service, ${ }^{21}$ or a web site that argues that, despite liberal assertions, ultra-Orthodox women enjoy equality. ${ }^{22}$

\section{B. Patriarchy: Second Dimension of Challenge}

The content of the web sites that we investigated reflects the very tight hierarchy in the ultra-Orthodox community and its patriarchal aspect. The dataset shows that in all segments of general society; secular, religious, and ultra-Orthodox, the majority of the surfers are men (see Graph 4 below). Yet, as Graph 4 demonstrates, the gender-based gap of Internet usage is more significant among the ultra-Orthodox than among the others. Only 35\% of Internet users among the ultra-Orthodox are women (the results are significant $(\alpha<0.001)$ ).

\footnotetext{
${ }^{20}$ MANOF, http://www.manof.org.il/, accessed January $15^{\text {th }} 2004$; ZOMET, http://www.moreshet.co.il/zomet/, accessed January 15 ${ }^{\text {th }}$ 2004; Chabad, http://www.ksol.org, accessed January $15^{\text {th }}$ 2004; and Hageoula, http://www.hageula.com/?CTopic=16, accessed January $15^{\text {th }} 2004$.

${ }^{21}$ Between Army and Yeshiva, http://www.geocities.com/tzava/, accessed January $15^{\text {th }} 2004$.

${ }^{22}$ The Voice of the Orthodox Women, http://www.geocities.com/orthodox women 2000/openinghebrew.html, accessed January $15^{\text {th }} 2004$.
} 


\section{Graph 4: Internet User\$ Gender}

(in percentages)

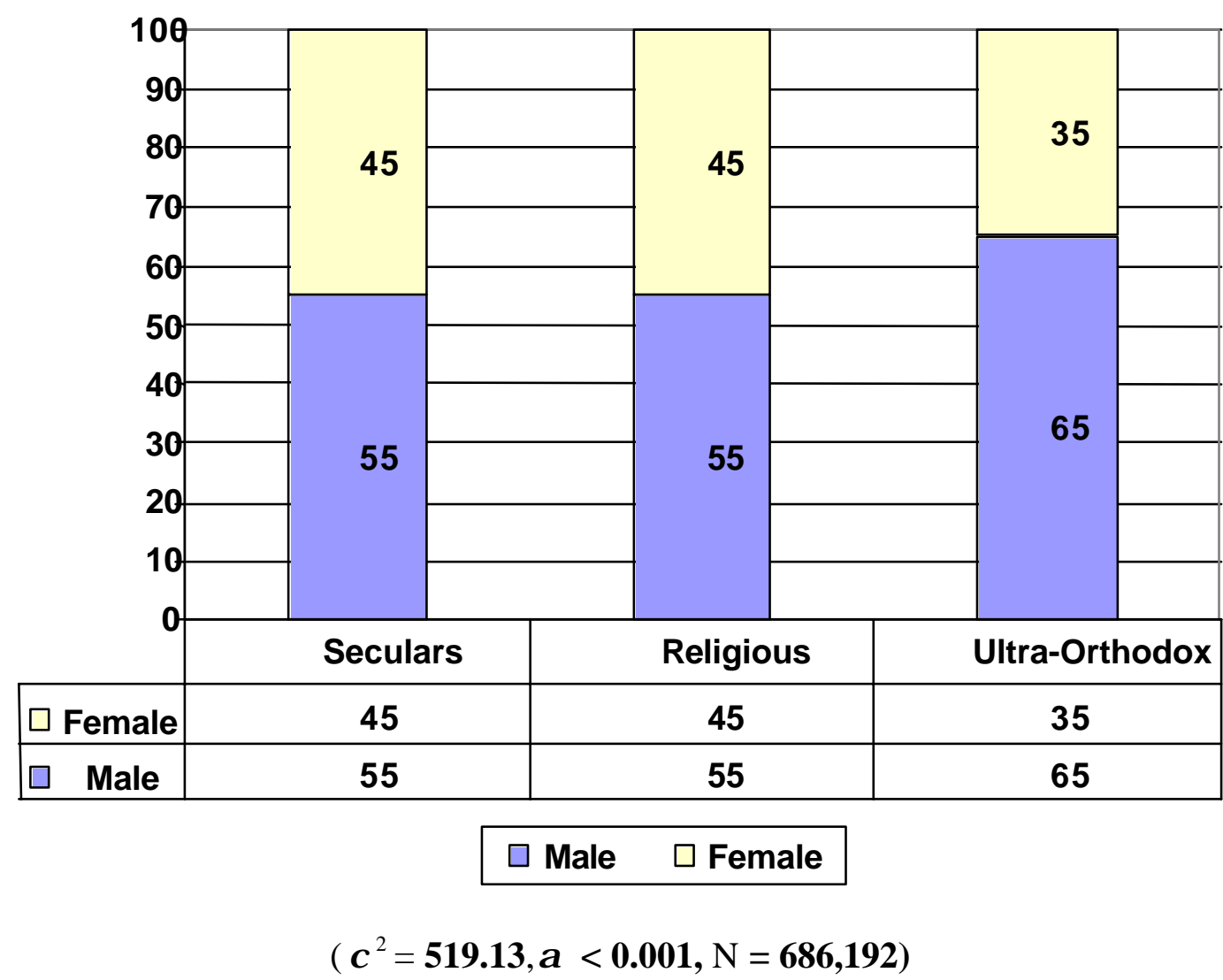

As explicated above, the issue of a gender-based digital divide is debated in the professional literature, and not all scholars agree that gender causes a digital divide. Our findings point out that ultra-Orthodox women have less access to the Internet and are significantly underrepresented among surfers. These findings are startling because Israeli ultra-Orthodox men study Halacha as their major vocation, especially until the age of 28. In turn, they are exempted from compulsory military service. Therefore, the job market is predominantly female, including professions that require Internet usage. Our findings, therefore, should be understood within the communal context of patriarchy, where a separate feminine voice is marginal and is formally prohibited in the public sphere (El-Or, 1994). Women are permitted to use the Internet as long as it assists men to study Halacha and is required in the job market. 
The ultra-Orthodox web sites noted above are perceived mainly gender-blind. ${ }^{23}$ Those that are devoted to ultra-Orthodox women generally describe them as obedient members of the community who enjoy egalitarianism. ${ }^{24}$ Liberal contentions that ultra-Orthodox women are deprived are vigorously rejected by ultra-Orthodox web sites as assertions of ignorance and hostility to religion.

\section{Discipline: Third Dimension of Challenge}

Ultra-Orthodoxy is highly unified around its spiritual leaders and the Halachic texts. The mobilization of community members to preserve the Halacha is maintained through its institutions, while deviations from communal aims and traditions are severely punished, e.g., by excommunication. The community maintains its own local law and courts, and rabbis as judges, as well as informal private arms of enforcement to punish deviant members (Barzilai, 2003) pp.209-278). Any technological innovation that the rabbinical elite suspects of being a menace is prohibited.

In January 2000, the ultra-Orthodox Council of Torah Sages signed a rabbinical ruling that condemned the Internet, computers, CD players, and films as dangerous, and called the Internet the "world's leading cause of temptation." ${ }^{25}$ Ultra-Orthodoxy strongly fears the intrusion of any information that may uncontrollably infiltrate the community. 'Temptation' in the religious fundamentalist community is another word for extreme disloyalty to the communal culture, placing its preservation under immense danger. There are two types of temptations that may be generated by the Internet and undermine discipline. First, the Internet may cause a misuse of time. The community renders little time for recreational activities, since such activities detract from learning the Halacha. Second, surfing the Internet may distract the mind and threaten the preservation of traditional values, through temptations and blasphemy like pornography, gambling, games and music.

Hence, secular communication channels create distrust among the ultra-Orthodox. Akin to any other religious fundamentalist community, they feel besieged by secular modernity that threatens its cultural preservation (Caplan, 2001). Consequently, the community has its own

\footnotetext{
23 see footnote 20

24 see footnote 22

25 see: Content Regulation, issue no. 139-16 January 2000, http://www.qlinks.net/quicklinks/content6.htm, accessed January $15^{\text {th }} 2004$.
} 
sources of communications, such as wall posters, local newspapers, communal TV satellite stations, printed commentaries on the weekly Torah portion, and audio and visual cassettes with special sermons and blessings by the rabbis (Caplan, 2001). All these channels, including those managed by media professionals, are under strict control and regulation by the rabbinical elite and are based on the language of the Halacha and Talmud.

The World Wide Web has received special attention as a source of perils to religious fundamentalists. The community cannot directly control the Internet. As already mentioned, Hypertext is a threat because of its non-linear, modular, multi-owned, interactive characteristics. Furthermore, once accessibility cannot be efficiently controlled, the user's ability to navigate in the virtual space is infinite and thus includes numerous encounters with secular sites.

Ultra-orthodox society does not encourage debates about its fundamentals as a religious collectivity. Conversely, the Internet, through its applications, enables debates among and between communities. Hence, from the communal perspective, not only should accessibility to the Internet be restricted and partly blocked, but also its content should be filtered before utilization. The level of communal discipline among ultra-Orthodox users is significantly higher even on secular platforms. As seen in Graph 5 below, the rate of complaints of ultraOrthodox members of virtual communities against each other is rather $\operatorname{low}^{26}(3.6 \%)$. Moreover, the high level of discipline is reflected in the low number of users expelled from the platform due to other members' complaints $(0.9 \%)$.

\footnotetext{
${ }^{26}$ Ultra-Orthodox online members interact with each other in various online communities. Members can file a complaint against other members in the very same virtual community. Complaints are checked by the virtual community enabler, and if found justified, the accused member is removed and cannot access this virtual community anymore.
} 


\section{Graph 5: Complaints Inside Virtual Communities and Removal of Users from Virtual Communities (in percentage)}

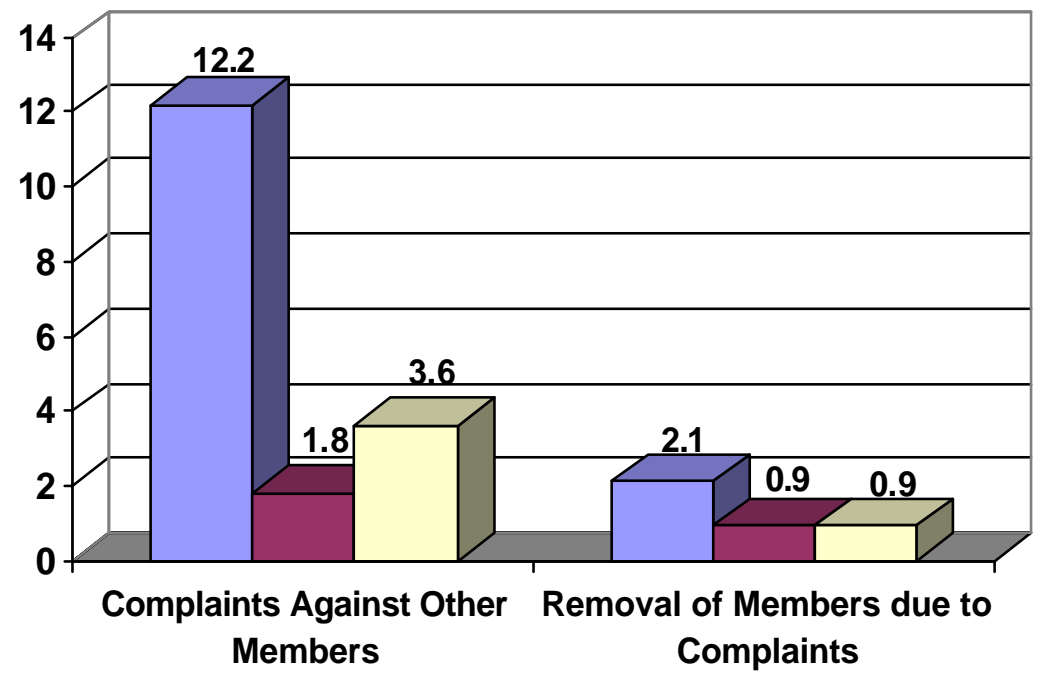

Seculars $\square$ Religious $\square$ Ultra-Orthodox

Not all virtual architectures that enable community activities provide identification of users. We have witnessed an interesting phenomenon where ultra-Orthodox anonymously use secular applications, mainly forums, ${ }^{27}$ to discuss communal and external issues. Anonymity may lead to less discipline, since the user is less fearful of being exposed and punished. Anonymous forums are outside the scope of the tight supervision of the religious fundamentalist authorities, and therefore, the debates may be more pluralistic and incite dissent against the community. For example, an ultra-Orthodox reporter claimed, in one of the forums entitled "In the Corridors of the Haredim," that the spiritual authorities have lost their legitimacy and power in the community (Dror, 2003). Had such an opinion been printed or aired in one of the ultra-Orthodox media channels, the reporter would have been excommunicated. In the virtual space, however, it incited some reactions of protest and nothing more.

Hence, under certain circumstances, the Internet has weakened discipline inside the ultraOrthodox community. If an opposition were raised in the traditional media, its exposure would have been minimal because of the tight monitoring within the community. The Internet has altered these traditional boundaries of communications. It has enabled a better

\footnotetext{
${ }^{27}$ A popular forum enabler platform in Israel is called Hydepark. Hydepark contains several forums of ultra Orthodox. See: http://www.hydepark.co.il, accessed January $15^{\text {th }} 2004$.
} 
exchange of views, especially through the secular platforms, without demolishing the ingroup structure of the community.

Ultra-Orthodox authorities feared this development. In one important instance, family relatives and intimate political advisors of the most prominent authority in Mizrachi ${ }^{28}$ ultraOrthodoxy, Rabbi Ovadia Yossef, were personally and directly criticized in one of the forums of Hydepark. A forum member accused them of secularism and heresy. Accusing the members of the most intimate circle around one of the most prestigious and popular ultra-Orthodox authorities in the $20^{\text {th }}$ century incited a public scandal. This was especially so, since Ovadia Yossef has been the unquestionable political leader of the ultra-Orthodox Mizrachi party, Shas, one of the strongest parties in Israel. Such criticism, true or false, could never have been published in the traditional ultra-Orthodox media. Since the user's personal identity remained anonymous, no internal communal punishment could be imposed against him/her. Hence, despite their political power, Yossef's relatives had to act outside their community and applied to the State's secular courts to sue the Internet forum for slander (Mor, 2003b).

Despite such scandals, most ultra-Orthodox users utilize the Internet for exchanging information about events in the community, the study of Halacha, to debate internal issues, and to comment on national affairs. From this perspective, the community's virtual facet complements its offline facet. The Internet has democratized the religious fundamentalist community, allowing various internal voices to be heard without having to drastically challenge the community from within and cause it to collapse. Paradoxically, IT has affected the community, has intruded into it, but has strengthened it as well.

\section{Seclusion - Fourth Dimension of Challenge}

As pointed out in the theoretical outline, the Internet has somewhat eroded the level of communal seclusion among religious fundamentalists. We will now explore the scope of the change within ultra-Orthodoxy. Traditionally, the ultra-Orthodox community has been isolated from its mainly secular surroundings. In return for its utilitarian recognition of the State, its autonomous structure has rendered most of the services to its members, inter alia,

\footnotetext{
${ }^{28}$ Mizrachi Jews are immigrants from Middle-East countries and North African Muslim countries who immigrated to Israel, mainly in the 1950s.
} 
education, arbitration, judicial processes, religious services, and social activities (Friedman, 1991, , Boyarin, 1997). Since the community has been collectively exempted from compulsory military service, the opportunities for cultural symbiosis with the seculars have been rather confined. Furthermore, most ultra-Orthodox groups are non-Zionist and have attempted to disconnect themselves from the State's ideology as much as possible.

Nevertheless, materialistic causes have stimulated more interactions between the community and its surroundings. Like other religious fundamentalist communities, the birth rate among the ultra-Orthodox is high, an average of about 6 children per family (Dahan, 1999). All men have to study in Yeshiva until the age of 28 to be exempt from military service. Women are prohibited from pursuing academic secular studies in secular institutions. Consequently, the community is very poor, the poorest among the Jewish population in Israel (Dahan, 1999). IT enables the ultra-Orthodox to interact with the global world while working at home, or in a work place within the community. Ultra-Orthodox women can now work in professions such as graphic design and architecture, without physically interacting with the secular community. In other words, the Internet has enabled the community to globalize itself economically and yet to retain its local characteristics, culturally. The figures from our dataset above testify that the ultra-Orthodox have their own unique characteristics as an online community. Paradoxically, the Internet has not demolished offline religious fundamentalism. Rather, the Internet has transformed religious fundamentalism to become more interactive with its surroundings online and the community has localized itself globally.

The drive to diminish seclusion through the Internet is also political, since the Internet is often used for communal mobilization. The spiritual leaders have concluded that since the Internet crosses boundaries within the community, it can be used as a means to recruit political support. Thus, ultra-Orthodox newspapers and the ultra-Orthodox party of Shas, have established web sites. When Ovadia Yossef was asked whether Shas is permitted to establish a web site, he replied: "we are allowed to fight them [the non-Orthodox Jews] with their own tools.'(Mor, 2003a). Unlike the Ashkenazi rabbis, who initially prohibited Internet usage formally, Yossef was more pragmatic. Since many Shas voters are not ultraOrthodox but Mizrachi traditionalist Jews, he desired to use the Internet to challenge other political parties that ordinarily used the Web, and to mobilize voters for Shas. 
Despite these trends of fuzzy boundaries between ultra-Orthodoxy and their surroundings, Graph 6 and Graph 7 below exhibit some elements of seclusion in the ultra-Orthodox community. Our dataset measures the association of members in virtual communities. Overall, the platform included 60,346 different virtual communities. We were interested in establishing whether religiosity affected the joining of various virtual communities. We presumed that the more secluded a community, the less its members are inclined to simultaneously join different virtual communities. Indeed, the findings show that among users who simultaneously join different communities, the ultra-Orthodox are associated only with $1 \%$ of the virtual communities on the platform. This number is significantly lower than the ultra-Orthodox overall online representation.

\section{Graph No. 6 - Association with Virtual Communities (in percentages)}

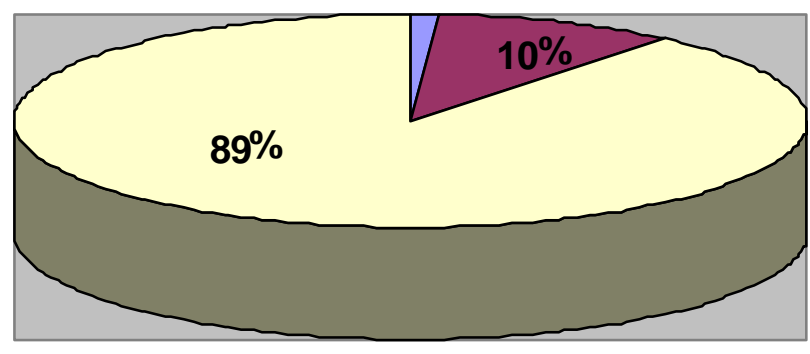

$\square$ Ultra-Orthodox $\square$ Religious $\square$ Seculars

$(\mathrm{N}$ (number of communities $)=60,346)$

Graph No.7 delineates four online activities among users in Israel: e-commerce, e- mail, forums, and gossip platforms. Under our community enabler, Hevre, two major aspects of online activities are prominent: those that are aimed only inward into the community (forums and the gossip platform), and those that may be cross-community (e-commerce and e-mail). The numbers presented below are the percentage of users that perform a certain online activity in their sector. The findings reveal that ultra-Orthodox are less inclined than religious and secular users to use application for cross-communal activities, such as ecommerce and e-mail. We see that 52.2 percent of online seculars use e-mail as compared to only 26.4 percent of online ultra-Orthodox. E-commerce is less common among all three sectors, though it is clear that the ultra-Orthodox transact less $(7.5 \%)$ as compared to the secular $(10.1 \%)$ and the religious (9\%). On the other hand, the ultra-Orthodox use to the same degree, or greater, online activities that can be exercised only internally, within the 
specific virtual community. For example, the ultra-Orthodox use forums more than any other sector.

\section{Graph 7: Online Activities (in percentages)}

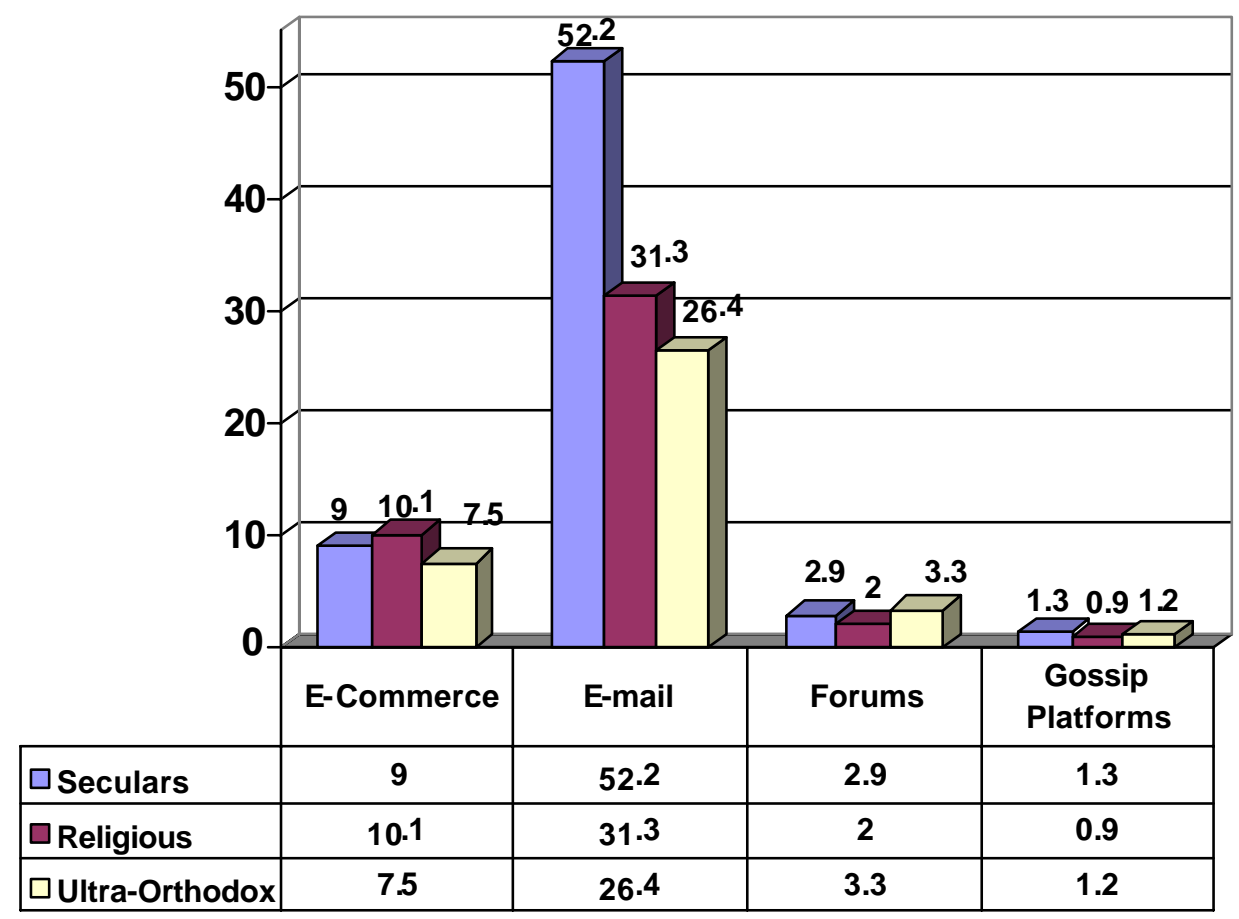

$\square$ Seculars $\square$ Religious $\square$ Ultra-Orthodox

(Shopping - 62,599, N Email- 334518, N Forums -19115, N Gossip Platforms - 8650)

Hence, despite the very complex set of interactions through the Internet and the challenges that religious fundamentalists have had to face in dealing with cyberspace, seclusion prevails, even if to a lesser degree than before the construction and adoption of the Internet.

\section{Conclusion: Community and Religion around Technology}

We have explored and conceptualized the junction of religious fundamentalism and Internet through four dimensions: hierarchy, patriarchy, discipline and seclusion, paying attention to the needs of communities to preserve their unique cultures. Religion, even in its fundamentalist hermeneutics and practices, does not perceive IT with irreversible hostility. In most religions, technology itself is perceived as a potentially friendly tool, or at least as a must, in order to disseminate religious texts and religious studies internally and externally. Additionally, it is being utilized for political purposes of mobilization and for economic 
reasons of more interactions in what seems as a global market. Cyberspace is dynamic in nature, fast and easy to access, providing users with more discretion, power and wealth of communication possibilities. These characteristics have rendered IT a special value among religious believers.

Through our study we offer a concept of cultured technology as a way to comprehend how religious fundamentalists adapt the Internet to their communities, and how technology has affected the internal and external boundaries of the community. The more concrete study of Jewish ultra-Orthodoxy demonstrates the complex processes that have injected the cyberspace onto the communal space, and how and to what degree the traditional structures of the community have been affected, preserved and even empowered. The ability to construct information technology has assisted religious fundamentalists not only to survive, but also to use it for their religious needs. As a result, the community has become more multifaceted and somewhat more pluralized, but also more empowered and more efficient by making the Internet a complimentary space for the offline community. The Internet has been localized, since its essence was altered and reconstructed. On the one hand, IT penetration has not drastically changed the basic foundations of the religious fundamentalist communities. On the other hand, we see more plurality in terms of hierarchy, patriarchy, discipline and seclusion.

\section{About the Authors:}

* Karine Barzilai-Nahon is an Assistant Professor in the Information School at the University of Washington. Formerly she held senior positions in Research and

Development in the hi-tech industry. She is the coordinator of the Communication and Informatics Committee for UNESCO. Her research deals with social and business aspects of the Internet and telecommunications.

E-mail for correspondence: karineb@u.washington.edu

** Gad Barzilai is Professor of Political Science and Law and the Co-Director of the Law, Society and Politics Program at Tel-Aviv University and currently a Visiting Professor in University of Washington. Formerly he held visiting positions of research and teaching at Yale and Berkeley universities. Barzilai has written extensively about law, politics and communities. His most recent book is: Communities and Law: Politics and Cultures of Legal Identities (Ann Arbor: University of Michigan Press, 2003). 
E-mail for correspondence: gbarzil@u.washington.edu

\section{Acknowledgements}

We would like to thank Mr. Shlomi Unger, co-founder of the virtual community enabler, Hevre, who gave us access, in good faith, to the dataset and who helped immensely throughout our research. Also, special thanks are due to Mr. Tal Harosh from Hevre who worked hard to provide us with the data. We are grateful to the anonymous reviewers and also to Michael Birnhack, Phillip Ein-Dor, Seev Neumann and Lorne L. Dawson for wise, valuable comments on earlier drafts and help.

\section{References}

Adamu, U. A. 2002. Islam and the Internet. KanoOnline, January 12. http://www.kanoonline.com/publications/islam_and_the_internet.htm (accessed September 20, 2003).

Asad, T. 1993. Genealogies of Religion: Discipline and Reasons of Power in Christianity and Islam. Baltimor: Johns Hopkins University Press.

Bachrach, P. and M. S. Baratz. 1970. Power and Poverty: Theory and Practice. New York: Oxford University Press.

Barzilai, G. 2003. Communities and Law: Politics and Culture of Legal Identities. Ann Harbor: University of Michigan Press.

Barzilai-Nahon, K. 2004. Gatekeepers and Gatekeeping Mechnanisms in Networks, PhD dissertation, Management of Technology and Information Systems Program, Tel Aviv University, Tel-Aviv.

Bastani, S. 2000. Muslim Women On-Line. Arab World Geographer 3(1):40-59.

Beeson, I. 2002. Exquisite Variety: Computer as Mirror to Community. Interacting with Computers 14(6):643-662.

Bimber, B. 2000. Measuring the Gender Gap on the Internet. Social Science Quarterly 81(3):868-876.

Boyarin, D. 1997. Unheroic Conduct. Berkeley: University of California Press.

Bunt, G. 2003. Islam in the Digital Age: E-jihad, Online Fatwas and Cyber Islamic Environments. London: Pluto Press.

Burt, R. 2000. The Network Structure of Social Capital. In Research in Organizational Behaviour, Vol. 22 eds. R. Sutton and B. Staw. Greenwich, CT: JAI Press.

Caplan, K. 2001. The Media in Haredi Society in Israel. Kesher 30.

Castells, M. 2000. The Rise of the Network Society. Oxford: Basil Blackwell.

Dahan, M. 1999. The Haredi Population in the Local Government [in Hebrew]. Jerusalem: Jerusalem Institute for Israel Studies. 
Davis, J. 2003. Terror Groups Use Anonymity, Cover of Web to Spread Message. Knight Ridder Newspapers, September 15.

http://www.realcities.com/mld/krwashington/news/nation/6778933.htm (accessed March 16, 2004).

Dawson, L. L. 2000. Researching Religion in Cyberspace: Issues and Strategies. In Religion on the Internet: Research Prospects and Promises, Vol. 8 eds. J. K. Hadden and D. E. Cowan, pp. 25-54. Elsevier Science Inc.

Dawson, L. L. 2001. Doing Rligion in Cyberspace: The Promis and the Perils. CSSR 30(1):3-9.

Dawson, L. L. 2004 forthcoming. The Meiation of Religious Experience in Cyberspace: A Preliminary Analysis. In Religion in Cyberspace, eds. M. Hojsgaard and M. Warburg. London: Routledge.

Dawson, L. L. and D. E. Cowan, eds. 2004 forthcoming. Religion Online, Routledge.

Dawson, L. L. and J. Hennebry. 1999. New Religions and the Internet: Recruiting in a New Public Space. Journal of Contemporary Religion 14(1):17-39.

DiMaggio, P., et al. 2001. Social Implication of the Internet. Annual Review Sociology 27.

Dror, Y. 2003. New Ultra-Orthodox Communities operate in the Internet without Rabbis [In Hebrew]. Haaretz, August 27. Tel-Aviv.

Edelman, B. 2002. Sites Blocked by Internet Filtering Programs. Expert report for Multnomah County Public Library et al., vs. United States of America, et al. http://cyber.law.harvard.edu/people/edelman/mul-v-us/.

El-Or, T. 1994. Educated and Ignorant: Ultra-Orthodox Jewish Women and Their World. Boulder, CO: Lynne Rienner.

Etzioni, A. 2003. Are Virtual and Democratic Communities Feasible? In Democracy and New Media, eds. H. Jenkins and D. Thorburn. Boston: MIT Press.

Fisher, D. J. and L. M. Wright. 2001. On Utopias and Dystopias: Toward an Understanding of the Discourse Surrounding the Internet. JCMC 6(2).

Friedman, M. 1991. Haredi Society: Sources, Trends, and Processes [in Hebrew]. Jerusalem: Jerusalem Institute for Policy Studies.

Gaist, I. 2003. Selected Social Indicators from data of social survey 2002 [in Hebrew], September 2, p. 5. Jerusalem: Central Bureau of Statistics. http://www.cbs.gov.il/hodaot2003/19_03_209.doc.

Glasner, J. 1999. Gender Gap? What Gender Gap? WiredNews, November 8.

Goulding, A. and R. Spacey. 2002. Women and the Information Society: Barriers and Participation, In 68th IFLA COuncil and General Conference, 10. Glasgow, Scotland.

Gutmann, A. 2003. Identity in Democracy. New Jersey: Princeton University Press.

Hadden, J. K. and D. E. Cowan, eds. 2000. Religion on the Internet: Research Prospects and Promises, London: Elsevier Science Inc.

Hampton, K. 2001. Living the Wired Life in the Wired Suburb: Netville, Glocalization and Civil Society, Doctoral Dissertation, Graduate Department of Sociology, University of Toronto, Toronto, Canada. 
Heller, H. 2000. Houshold Expenditure Survey 1999 in Large Cities [in Hebrew]. Central Bureau of Statistics, September 6. http://www.cbs.gov.il/hodaot2000/19_00_203.htm (accessed September 27, 2003).

Heller, H. 2001. Houshold Expenditure Survey 2000 in Large Cities[in Hebrew]. Central Bureau of Statistics, November 7. http://www.cbs.gov.il/hodaot2001/19_01_260.htm (accessed September 27, 2003).

Heller, H. 2002. Findings about the 12 Biggest Cities in Israel, from 2001 Household Expenditure Survey [in Hebrew]. Central Bureau of Statistics, October 23. http://www.cbs.gov.il/hodaot2002/05_02_244.htm (accessed September 27, 2003).

Hoffman, D., T. Novak and A. Schlosser. 2000. The Evolution of Digital Divide: How Gaps in Internet Access may Impact Electronic Commerce. JCMC 5(3).

Hojsgaard, M. and M. Warburg, eds. 2004 forthcoming. Religion in Cyberspace, London: Routledge.

Hoover, S. M., L. S. Clark and L. Rainie. 2004. Faith Online, April 7, p. 28. Washington D.C.: Pew Internet \& American Life Project. http://207.21.232.103/pdfs/PIP Faith_Online 2004.pdf.

Hostetler, A. J. 1993. Hamish Society. Baltimore: Johns Hopkins University Press.

Jasperson, J., et al. 2002. Review: Power and Information Technology Research: A Metatriangulation Review. MIS Quarterly 26(4):359-397.

Katz, J. E. and M. A. Aakhus. 2002. Making Meaning of Mobiles - a Theory of Apparategeist. In Perpetual Contact: Mobile Communication, Private Talk, Public Performance, eds. J. E. Katz and M. A. Aakhus, pp. 301-320. Cambridge: Cambridge University Press.

Kling, R. 2000. Learning about Information Technologies and Social Change: The Contribution of Social Informatics. The Information Society 16:217-232.

Landow, G. and P. Delany. 1991. Hypertext, Hypermedia and Literary Studies: The State of the Art. In Hypermedia and Lietrary Studies, eds. G. Landow and P. Delany, pp. 350. Cambridge, MA: MIT Press.

Larsen, E. 2000. Wired Churches Wired Temples: Taking Congregations and Missions into Cyberspace, p. 22. Washington D.C: Pew Internet \& American Life.

Larsen, E. 2001. CyberFaith: How Americans Pursue Religion Online, December 23, p. 21. Washington D.C: Pew Internet \& American Life. http://www.pewinternet.org/reports/pdfs/PIP_CyberFaith_Report.pdf.

Lawrence, B. 2000. Shattering the Myth: Islam Beyond Violence. NJ: Princeton University Press.

Lebo, H. 2003. The UCLA Internet Report: Surveying the Digital Future - Year Three, February, p. 89. Los-Angeles: UCLA Center for Communication Policy. http://ccp.ucla.edu/pdf/UCLA-Internet-Report-Year-Three.pdf.

Lee, G. 1997. Addressing Anonymous Messages in Cyberspace. JCMC 2(1).

Liebman, C. S. 1993. Jewish Fundamentalism and the Israeli Polity. In Fundamentalism and the State, Vol.3, eds. M. E. Marty and S. R. Appleby. Chicago: University of Chicago Press.

Liebman, C. S. and E. Katz, eds. 1997. The Jewishness of Israelis, Albany, NY: State University of New York Press. 
Lukes, S. 1974. Power: A Radical View. London: Macmillan.

Machlis, A. 2003. Can Israeli Rabbis Enforce their Ban against the Internet? Jewsish Bulletin New of Northern California, http://www.jewishsf.com/bk000121/iinternetban.shtml (accessed July 9, 2003).

Marty, M. E. and S. R. Appleby, eds. 1991. Fundamentalism Observed, Vol. 1, University of Chicago Press.

Marty, M. E. and S. R. Appleby, eds. 1993. Fundamentalism and the State, Vol. 3, University of Chicago Press.

Marty, M. E. and S. R. Appleby, eds. 2004. Fundamentalisms Comprehended, Chicago: University of Chicago Press.

Mor, G. 2003a. Shas Online [in Hebrew]. Ynet, January 15. http://www.ynet.co.il/Ext/Comp/ArticleLayout/CdaArticlePrintPreview/1,2506,L2376595,00.html (accessed September 30, 2003).

Mor, G. 2003b. Slander Suit against "Hydepark" Site [in Hebrew]. Ynet, June 10. http://www.ynet.co.il/Ext/Comp/ArticleLayout/CdaArticlePrintPreview/1,2506,L2653253,00.html (accessed September 30, 2003).

Ono, H. and M. Zavodny. 2003. Gender and the Internet. Social Science Quarterly 84(1):111-121.

Peled, A. 2000. Debunking the Internet Myth: Technological Prophecies and Middle East Politics. The Middle East Quarterly 7(3).

Perlmutter, D. 2002. Skandalon 2001: The Religious Practices of Modern Satanists and Terrorists. Anthropoetics 7(2).

Pfeffer, J. 1994. Managing with Power: Politics \& Influence in Organizations. Harvard Business School Press.

Pickering, W. 1984. Durkheim's Sociology of Religion. London: Routledge.

Privacy International and GreenNet Education Trust. 2003. Silenced: An International Report on Censorship and Control of the Internet, September. London. http://www.privacyinternational.org/survey/censorship/.

Putnam, R. 2000. Bowling Alone: The Collapse and Revival of American Community. A Touchestone Book.

Rafaeli, S. and F. Sudweeks. 1998. Interactivity on the Nets. In Network and Netplay: Virtual Groups on the Internet, eds. F. Sudweeks and M. McLaughlin. Menlo Park, CA: MIT Press.

Ramos, D. 2002. The Veiled Ummah of Islam find their voices on the Internet. http://www.nyu.edu/classes/keefer/joe/ramos1.html (accessed September 29, 2003).

Rebibo, Y. 2002. Back from Utopia [in Hebrew]. Tchelet, Spring. http://www.azure.org.il/hebrew/12-rebibo.html (accessed September 29, 2003).

Robertson, R. 1995. Time-Space and Homogeneity-Heterogenity. In Global Modernities, eds. M. Featgerstone, S. Lash and R. Robertson, pp. 25-44. London: Sage Publications.

Rosenblum, J. 2000. Of Ostriches and Caveman Jerusalem Post, January 21. http://www.jewishmediaresources.com/article/53/ (accessed September 24, 2003). 
Rozen, L. 2003. Forums Point the Way to Jihad. WiredNews, August 6. http://www.wired.com/news/print/0,1294,59897,00.html (accessed September 20, 2003).

RSF. 2003. The Internet Under Surveillance: Obstacles to the Free Flow of Information Onlins, July, p. 151. Reporters Without Borders.

Schechter, E. and S. Ser. 2000. God's Workers: Ultra-Orthodox Jews Make their Way into the World of High Tech RedHerring, September.

http://www.redherring.com/mag/issue82/mag-god-82.html (accessed September 23, 2003).

Spigelman, S.-1. 2000. Islam and Internet: The Correlation between Islamic Religion and Internet Diffusion, p. 24. Harvard, John F. Kennedy School of Governanment. http://www.ksg.harvard.edu/iip/stp305/Fall2000/spigelman.PDF.

Tonn, B. E. and E. Ogle. 2002. A Vision for Communities in the 21st. Century: Back to the Future. Futures 34(8):717-734.

Weber, M. 1946. Politics as a vocation. In From Max Weber: Essays in Sociology, eds. H. Gerth and C. Wright Mills, pp. 77-128. New York: Oxford University Press.

Weber, M. 1947. The Theory of Social and Economic Organization. New York, NY: Free Press.

Weber, M. 1964 (1922). The Sociology of Religion. Boston: Beacon Press.

Wellman, B. 2001. Does the Internet Increase, Decrease or Supplement Social Capital? American Behavioral Scientist 45(3):437-456.

Wellman, B. 2002. Little Boxes, Glocalization and Networked Individualism. In Digital Cities II: Computational and Sociological Approaches, eds. M. Tanabe, P. van den Besselaar and T. Ishida. Berlin: Springer.

Wellman, B., J. Boase and W. Chen. 2002. The Networked Nature of Community: Online and Offline. IT\&Society 1(1):151-165.

Wills, D. 1999. The Nature of Hypertext: Background and Implication for Librarians. The Journal of Academic Librarianship 25(2):134-139. 